\title{
Leiers wat dien en bédien. 'n Pauliniese beskrywing van kerkleiers en hulle funksies in 1 \& 2 Korintiërs
}

\author{
$\mathrm{J}_{\text {Vermeulen }}{ }^{1}$ \\ (Universiteit van Pretoria)
}

\begin{abstract}
Leaders that serve and minister. A Pauline description of church leaders and their functions in 1 \& 2 Corinthians

What constitutes the functions and the essence of Pauline church leadership? How functional, relevant and useful is the huge amount of secular and religious literature published annually regarding leadership, for the church of Jesus Christ? In an effort to answer these and other questions, this essay studies portions of First and Second Corinthians, and comes to two conclusions. Firstly, that Pauline church leaders were characterised by service and servanthood, and secondly, that they also functioned as the mediators of pneumatological realities. Both of these dimentions function wholly within the paradigm of humility and dependance upon God, who is shown by Paul to be the source, as well as the focus of the superlative glory that characterises the ministry of the new covenant. The effects of the Pauline ministry functions simultaneously as the fruits, as well as the criteria of Pauline ministry in the new covenant.
\end{abstract}

\section{INLEIDENDE OPMERKINGS}

Wat is die funksies van kerkleiers in die Pauliniese briewe? Wat is die wesensaard van die Pauliniese bediening? Antwoorde wat gesoek word op vrae wat sekerlik relevant en aktueel is vir die hedendaagse kerk van Jesus Christus. In ' $n$ poging om moontlike antwoorde te verskaf op hierdie uiters belangrike vrae, word onderskeidelik 1 Korintiërs $3-4$, asook 2 Korintiërs 3 in hierdie artikel eksegeties verken. Ook die Griekse woorde wat Paulus in hierdie gedeeltes gebruik om sy bedieningsaktiwiteite aan te dui, word vlugtig ondersoek.

\section{LEIERSKAP: “DIE KLEED MET BAIE KLEURE”}

Daar bestaan vele definisies van leierskap. Nadat Stogdill (1981:7) een van die mees uitgebreide oorsigte tot nog toe van antieke en hedendaagse studies $^{2}$ en publikasies met betrekking tot leierskap en die gepaard-

\footnotetext{
1 Artikel gebaseer op doktorale proefskrif voltooi onder leiding van Prof J G van der Watt, Departement Nuwe Testament, Universiteit van Pretoria.

2 Antieke leierskap word hoofsaaklik in die verbygaan behandel. Die gewig van sy studie lê by die hedendaagse navorsing in dié verband.
} 
gaande funksies van leierskap gedoen het, kom hy tot die volgende gevolgtrekking: "There are almost as many definitions of leadership as there are persons who have attempted to define the concept."

Bennis en Nanus (1985) lys byvoorbeeld ongeveer drie honderd en vyftig definisies van leierskap in hulle studie. Volgens Bass (1990:11) is daar min onderwerpe waaroor so baie geskryf is in onlangse jare, as juis oor leierskap. Ten spyte hiervan, bly leierskap, volgens Bass, egter steeds 'n grootliks onbekende, on-eksakte onderwerp, omring met ' $n$ ondeurdringbare misterie. Om hierdie veelheid van opinies te illustreer, som Bass (1990:11) 'n paar algemene definisies van leierskap op wat in die literatuur voorkom:

"Leadership has been conceived as the focus of group processes, as a matter of personality, as a matter of inducing compliance, as the exercise of influence, as particular behaviours, as a form of persuasion, as a power relation, as an instrument to achieve goals, as an effect of interaction, as a differentiated role, as initiation of structure, and as many combinations of these things".

John Maxwell (1991:11), bekende leierskapkenner in die VSA, sluit by een van die moontlikhede hierbo aan met sy definisie: "The true measure of leadership is influence-nothing more, nothing less."

Tom Marshall (1991:9) sluit ook aan by een van Bass hierbo se definisies: "The first characteristic of leaders is that they are going somewhere...they are aiming at goals or objectives that lie in the future. Their interest therefore is in what is to come rather than in what is past."

Teen die agtergrond van hierdie skynbaar universele verwarring ten opsigte van die spesifieke aard van algemene leierskap, word die misterie nog groter as ons vra na die spesifieke aard van Nuwe-Testamentiese (in dié geval, Pauliniese) kerkleierskap! Hoe sal 'n definisie van Pauliniese leierskap vergelyk met bovermelde sekulêre definisies van leierskap en die veronderstelde funksies van leierskap? Sekere definisies mag goed werk in ' $\mathrm{n}$ sekulêre verband, maar heeltemal onvanpas wees in ' $n$ Nuwe-Testamentiese, kerklike konteks. Die doel van hierdie artikel is dan juis om deur middel van die eksegese van gedeeltes uit 1 en 2 Korintiërs 'n poging aan te wend om by ' $n$ teologies gefundeerde definisie van leierskap uit te kom, wat bepaald anders kan lyk as die algemene definisies hierbo vermeld. 


\section{TERMINOLOGIESE BESKRYWINGS VAN SEKULÊRE LEI- ERS EN FUNKSIONARISSE IN DIE EERSTE EEUSE, MEDI- TERREENSE WÊRELD}

In die Grieks-Romeinse wêreld van die eerste eeu was daar ' $n$ paar moontlikhede waarmee bedienaars van die kerk aangedui kon word, naamlik:

i telos ('n amptenaar of vrywillige diens deur 'n burger);

ii timé (amp of opdrag met die klem op die waardigheid van die persoon of taak);

iii argé (amp/magistraat/leier van volgelinge) en

iv leitourgia (Du Rand 1988:79,80; Schweizer 1992:835).

$\mathrm{v} \quad$ Paulus kies egter vir ' $\mathrm{n}$ ander, ietwat seldsame woord met ' $\mathrm{n}$ totaal sekulêre konnotasie om sy bediening te beskryf, naamlik diakonia.

\section{PAULUS SE OPMERKINGS IN 1 KORINTIËRS 3:1-4:21 TEN OPSIGTE VAN KERLEIERS}

Hier volg enkele opmerkings ten opsigte van die aard van die Christelike bediening uit 1 Korintiërs $3: 1-4: 21^{3}$. In 1 Korintiërs $3: 1-4: 13$ weerlê Paulus ' $\mathrm{n}$ foutiewe persepsie van die bediening, wat tesame met ' $\mathrm{n}$ valse konsep van "wysheid", aan die wortel lê van die Korintiërs se verdeeldheid. In 4:14-21 maak hy 'n appél op hulle om hulle verdeeldheid te staak (Fung 1982:130). In 1 Korintiërs 3:5-11 skryf Paulus die volgende:

Wat is Apollos dan? Wat is Paulus? Hulle is maar net dienaars (diakonoi) deur wie julle tot geloof gekom het, en elkeen doen die werk soos die Here dit vir hom gegee het. Ek het geplant, Apollos het natgegooi, maar dit is God wat laat groei het. Ons is medewerkers (sunergoi) in diens van God, en julle is die saailand van God.

\subsection{Die terme waarmee Paulus kerkleiers soos hyself en Apollos beskryf}

i Hulle is diakonoi (diensknegte of slawe), deur wie die Korintiërs tot geloof gekom het (1 Kor 3:5). Oor die algemeen dui die woord op "slawe" (douloi) of "diensknegte". Al hulle arbeid is altyd ondergeskik aan die heerskappy van Christus, omdat hulle medewerkers (s unergoi i) van God is - 3:9; (Fung 1982:131).

3 Vir " $n$ goeie studie van Paulus se konsep van "bediening" in 1 Korintiërs, vergelyk die artikel van Brister (1983:19-32). 
ii Verder is hulle uphret $h \sim(1$ Kor $4: 1,2)$ wat ongeveer dieselfde betekenis het as eersgenoemde hierbo. Volgens Brister (1983:23) dui uphret $\mathrm{h} \sim$ op, "an under-rower, one serving as an oarsman at the water level of a ship... the founder claimed a role of hard, humble toil for the leaders."

Jphreth is verwant aan en waarskynlik afgelei van gerapeuw, uphret ew en diakonew, wat almal dui op dienslewering deur diensknegte of slawe. Heeltemal tereg plaas Louw en Nida (1989:460-461) dan ook hierdie woorde in dieselfde semantiese veld, naamlik die van "serve". L eitourgia en doulo word ook in hierdie semantiese veld geplaas.

i Leiers is volgens Paulus (1 Kor 4:1,2) ook oikonomou , wat dui op slawe wat as bestuurders van huishoudings aangestel is; 'n administrateur, of die stadstesourier (Louw \& Nida 1989: 173).

ii Verder gebruik Paulus die analogie van die boer wat plant en natgooi in 1 Korintiërs 3:6 om die eenheid tussen hom en Apollos te beskryf. In hierdie aktiwiteit is Paulus-hulle sunergoi; van God.

iii In 1 Korintiërs 3:10 sien Paulus homself ook as ' $\mathrm{n}$ vaardige bouer wat die tempel van God bou. Die gemeente is die kosbare edelstene, goud en silwer wat deur hom neergelê word.

Omdat die "bediening" aan die kerk behoort en die kerk dien, is dit deel van die kerk en afhanklik daarvan - nooit onafhanklik nie (1 Kor 3:21). Christenbedienaars is verenig in 'n onlosmaaklike eenheid van wese en doelwit (1 Kor $3: 8,9 ; 4: 1)$. Christenbedienaars is verder geroep om rolmodelle vir die kerk te wees (1 Kor 4:16; Fung [1982:131]).

\section{VERDERE OPMERKINGS TEN OPSIGTE VAN DIE BETE- KENIS VAN DIE WOORD, DIAKONIA}

Paulus gebruik die woord diakonoi (bedienaars) en diakonia (bediening) ook in 2 Korintiërs 3:6 en 7 om sy aktiwiteite te beskryf ${ }^{4}$. Die rede vir die aanwending van hierdie woord is waarskynlik gedeeltelik te danke aan die prominensie wat Jesus aan hierdie woord gegee het tydens sy aardse bediening wat die basis van sy dissipels se bediening gevorm het. In 2 Korintiërs 5:18 beskryf Paulus sy bediening byvoorbeeld as: thn diakonian th $\sim$ katallagh $\sim$ ("die bediening van versoening"). Daar was egter sekere negatiewe konnotasies vanuit die Joodse en heidense tradisies met betrekking tot die woord diakonia (Schweizer

4 Ook in 1 Korintiërs 3:5, 2 Korintiërs 11:23; 6:3 en Handelinge 20:24 
1992:836). In die Judaïsme (LXX) word I eit ourgew gebruik om dieselfde betekenis aan te dui, aangesien diakonia op daardie stadium waarskynlik nog op minderwaardigheid gedui het (Josefus en Philo Beyer [1985:153]).

\subsection{Die naamwoord diakoni $a$ in buite-Bybelse bronne}

Die woord word deur Plato en Tukidides gebruik om te dui op: "the office of a diakonos", asook die waarneem van een of ander diens. Demetrius gebruik die woord om die daaglikse voorsiening van behoeftes aan te dui (Liddell \& Scott 1989:189). Die LXX gebruik die woord om op tafeldiens te dui (Schweizer 1992:836).

\subsection{In die Nuwe Testament dui die naamwoord diakoni $a$, volgens}

Louw \& Nida (1989:59) op “-service, -ministry, -provision, -waiting upon, -contribution". Die Nuwe-Testamentiese gebruik stem dus grootliks ooreen met die van die buite-Bybelse gebruik.

\subsection{Die werkwoord diakonewbeteken in buite-Bybelse bronne,}

i "to wait at a table, -to care for, -to serve a person" (Beyer 1985: 152-154). Demetrius gebruik dit in die konteks van persoonlike diens, terwyl die woord vir Plato dui op diensbaarheid. Sofokles gebruik die woord om te dui op die versorging van jou eie behoeftes (Liddell \& Scott 1989:189). Alhoewel diak onew gebruik word in relasie tot die huishouding, dui dit gewoonlik op diens deur ' $n$ amptenaar in ' $n$ amptelike, godsdienstige of publieke konteks.

ii Verder word diakonew gebruik om "n "koerier", "middelaar" of "tussenganger" se aktiwiteite aan te dui (Collins 1990:77). Diako kan dui op iets soos " $\mathrm{n}$ boodskapper wat iets aflewer, asook iemand wat op 'n sending is (Collins 1990:107).

iii ' $n$ Ander betekenis van diakonew dui op die uitvoering van ' $n$ daad, of die uitvoering van ' $n$ taak. Dit is ook nie noodwendig ' $n$ minderwaardige taak nie (Collins 1990:133-149), omdat Josefus byvoorbeeld " $\mathrm{n}$ diakonos beskryf as "the duly sanctioned representative of the Jewish God" (Donfried 1992:124). Jphreth word ook in hierdie sin aangewend (Louw \& Nida 1989:460).

\subsection{Die werkwoord diakonewbeteken in die Nuwe Testament, "to} -serve, -take care of, -to wait upon, -to be a deacon", en "-to handle finances" (Louw \& Nida 1989:59).

\subsection{Verder dui die selfstandige naamwoord diakono , volgens} Louw \& Nida (1989:59) op, "-servant of a master, -deacon, -minister". Paulus gebruik die woord ook om die funksie van die owerhede te beskryf. Dit wil dus voorkom asof hierdie woord, volgens Paulus, primêr 
dui op enige persoon of instansie wat deur God aangestel is om ' $n$ sekere taak te verrig, met die klem op die aspek van dienslewering. Dit is, volgens Collins hierbo, ook nie noodwendig die lewering van slawe-arbeid en minderwaardige takies nie ${ }^{5}$. Fung (1982:130) beskryf die essensie van hierdie woord as "a service rendered in humility and love".

Dit blyk duidelik uit bovermelde omskrywings, dat Paulus sy eie, sowel as sy medewerkers se aktiwiteite primêr gesien het as dienslewering aan God en die gelowiges. Paulus (en die ander apostels) is waarskynlik hierin beïnvloed deur die voorbeeld van diensknegleierskap wat Jesus self gestel het tydens sy aardse bediening. Jesus se standpunte ten opsigte hiervan word op verskeie plekke soos Markus 10:41-45, Matteus 20:20-28 en Lukas 22:24-30 ondubbelsinnig en kragtig deur homself geartikuleer. Green (1996:44) bevestig hierdie perspektief soos volg:

Grootheid in die koninkryk word verkry deur diens. Jesus wil sy dissipels bevry van afguns en naywer en hul saamsnoer tot ' $n$ eenheid waarin elkeen die ander waardiger ag as homself... Hierdie eenheid word dan bewaar deur die onderlinge diensbetoon deur die broers in die gemeente... In teenstelling met die nasies se regeerders, wat regeer volgens die beginsels van "baasspeel" en "magsmisbruik"... vestig Jesus die grondbeginsel van grootheid deur diens.

Paulus gebruik ook die woord doulo (slaaf) selfstandig, of saam met diakono om sy werk te beskryf. Die wyse waarop Paulus diakono met sy verbuigings in die tweede brief aan Korintiërs aanwend gee ons 'n goeie idee wat hy beskou het as die wesensaard van die woord. $\mathrm{Na}$ die gevolgtrekking wat hieronder volg, sal aan die gedeelte aandag gegee word $^{6}$.

\subsection{Eerste gevolgtrekking}

Die eerste gevolgtrekking wat ons kan maak uit die leksikografiese data hierbo, is dat Paulus, deur sy gebruik van woorde soos diakono , doul $0 \sim$, uphreth $\sim$ en I eit ourgia, wou dui op die feit dat kerkleiers, soos hy en Apollos, slegs dienaars was van Christus en die kerk. Hulle was bloot slawe en diensknegte, en nie heersers of diktators nie. Hulle diensskap het nie noodwendig ' $n$ minderwaardigheid geïmpliseer nie. Inteendeel, hulle was diensknegte op 'n Goddelike sending. Käsemann (in Fung 1984:10) som hierdie gevolgtrekking treffend op: "No spiritual

5 Dit is die klem van Collins se uiters breedvoerige studie van veral die buiteBybelse aanwending van die woord, asook die artikel van Donfried.

6 Vergelyk Wehrli (1992:103-107) en Messer (1989:29-32) vir 'n verdere goeie bespreking van die woord hierbo. 
endowment has value, rights and privileges on it's own account. It is validated only by the service it renders."

\section{DIE SINTAKTIESE OPBOU VAN 2 KORINTIËRS 3:4-8: DIE VERHOUDING TUSSEN DIAKONIA EN PNEUMA}

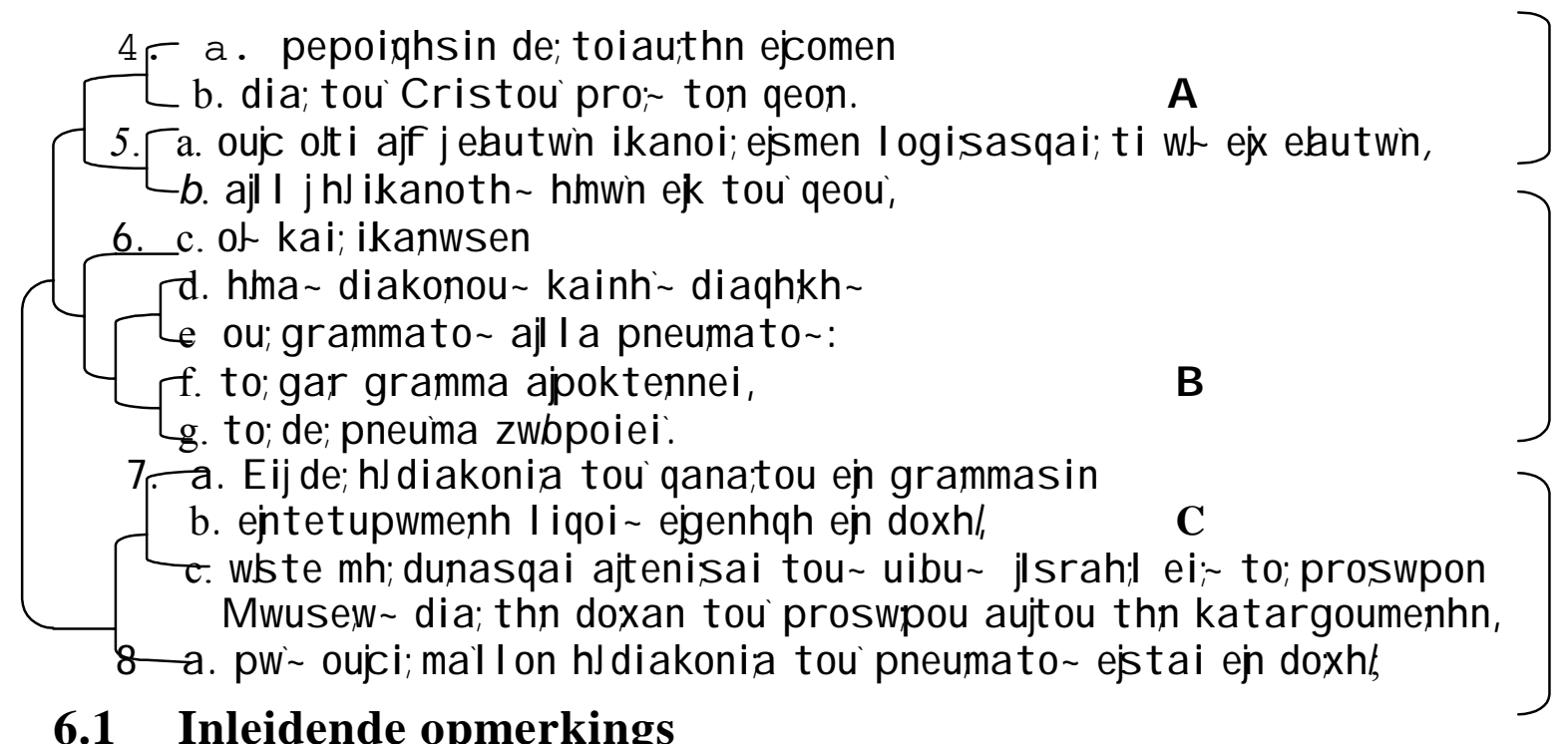

\subsection{Inleidende opmerkings}

Paulus se apologia hierbo (verse 4-8), begin alreeds in 2 Korintiërs 2:14, en word voltooi in 3:18 (Lambrecht 1999:43). Hy polemiseer teen die valse predikers wat met hulle aanbevelingsbriewe ingang probeer vind in die gemeente, sodat hulle met die evangelie handel kan dryf (kaphleupnte $)$. Paulus transponeer die analogie van aanbevelingsbriewe wat op papier met ink geskryf is, deur te verklaar dat die hele gemeente sy aanbevelingsbrief is, deur Christus self geskryf. C r is t ou ' is hier waarskynlik 'n subjektiewe genitief, en nie 'n objektiewe genitief nie. Die gemeente is dus ' $n$ brief wat deur Christus geskryf is, en nie bloot ' $n$ brief met Christus as inhoud nie (Barnett 1997:167). Paulus daarenteen, se aanbevelingsbrief is nie met ink op kliptablette geskryf nie (soos met die dwaalleraars die geval is nie), maar is deur "die Gees van die Lewende God" ("n hapax in die Nuwe Testament) op menslike harte geskryf.

\subsection{Die Pauliniese antitese tussen die ou en nuwe verbonde}

Paulus se verwysing na die kliptablette berei die weg vir sy hoof antitese, naamlik tussen die ou en die nuwe verbonde, asook tussen die bedienaars van hierdie verbonde. Paulus verbind die kliptablette van Moses se verbond direk met die aanbevelingsbriewe van die dwaalleraars, en lê daarmee ' $n$ verband tussen die bediening van die dwaal-leraars en die (nou skynbaar irrelevante) verbond van Moses (Barnett 1997:160). Die vervanging van aanbevelingsbriewe op papier en klip, met dié op menslike harte, dui op die vervulling van die profesieë van Jeremia $(31: 33 ; 38: 31-34)$ en Esegiël $(36: 26,27)$ met betrekking tot die 
nuwe verbond wat moes kom (Klauck 1988:36). Die nuwe verbond word gekenmerk deur die feit dat dit verinnerlicht word (Klauck 1988:36). Die nuwe verbond impliseer ook dat ' $\mathrm{n}$ ander tipe bedienaar nou nodig is. Paulus se argument in dié verband, soos aangetoon by die sintaktiese opbou van 2 Korintiërs 3:4-8 hierbo, verloop in drie dele, naamlik A, B en $\mathrm{C}$ :

A Alhoewel Paulus die idee van aanbeveling verwerp (vers een), verhoed dit hom nie om na sy eie bron van bekwaamheid (ika not $h \sim$ ) te verwys nie, naamlik God (Barnett 1997:171, 173). Hiermee beantwoord Paulus die vraag wat hy in 2 Korintiërs 2:16 gevra het rakende die bron van hulle bekwaamheid as Nuwe-Testamentiese bedienaars (Kremer 1990:37; Klauck 1988:36). Hierdie gedagte word deur Paulus voortgesit met sy opmerkings oor die bediening in 2 Korintiërs 5:17-21, asook Galasiërs 1:11-12, 15-16. Hierdie bekwaamheid wat God gee, is die geheim van sy vrymoedigheid (pepoighs in) (Fung 1982:133). Die verbuigings van die woord "bekwaam" is "n belangrike konsep in Paulus se apologia, en ons vind dit in 2 Korintiërs 2:16 en 3:5a as 'n byvoeglike naamwoord (ika no $\sim$ ); in 3:5b as 'n naamwoord (ika not $h \sim$ ), en in 3:6 as ' $n$ werkwoord (ikanwsen) (Lambrecht 1999:43). Die bron van sy bekwaamheid bepaal immers die kwaliteit van sy bediening. Alhoewel Paulus die self-bekwaamheid van die dwaalleraars verwerp, is hy nie gekant teen die idee van vrymoedigheid nie. Die enigste voorwaarde is dat ' $n$ bedienaar se vrymoedigheid en bekwaamheid deur God se Gees gesanksioneer moet wees (Barnett 1997:171).

B Hierdie gedeelte beskryf waarvoor Paulus bekwaam gemaak is. God het hom bekwaam om as ' $\mathrm{n}$ bedienaar (diakono $)^{7}$ op te tree van die nuwe verbond (kainh $\sim$ diaghkh ). Die selfstandige naamwoord, diakono verskyn hier vir die eerste keer. Soos hierbo aangetoon, verwys hierdie woord na ' $\mathrm{n}$ persoon wat ander prakties dien (nie noodwendig minderwaardige takies nie - vergelyk Barnett [1997:174]). Diakono figureer ook in 1 Tessalonisense 3:2 en, soos reeds vermeld in 1 Korintiërs 3:5. Verbuigings van die woord kom ses en dertig keer voor in Paulus se briewe, waarvan twintig keer in 2 Korintiërs (konstitueer $56 \%$ van sy gebruik). Alhoewel dit moontlik is dat die dwaalleraars in Korinte prominensie aan hierdie woord verleen het, het hulle nie die gebruik daarvan geïnisieer nie aangesien dit te dikwels figureer op ander plekke (Barnett 1997:174). Paulus werk met 'n antitese tussen die nuwe en die ou verbonde wat hy ontwikkel aan die hand van drie aspekte, naamlik:

7 Volgens die bespreking van die woord diakono en sy verbuigings hierbo vir volledigheid. 
i Die nuwe verbond kwalifiseer hy as die verbond van die Gees (p neumat $0 \sim$ ) wat lewe bring. Die ou verbond was die verbond van die woord/letter (g r a mmat $0 \sim$ - Sinaï se tien gebooie), wat die dood gebring het (Fung 1982:133, 134). Winger (1992:34) bevestig die feit dat Paulus gramma en nomo skynbaar as parallelle gebruik wat beide op die wet van Moses dui. Volgens Winger (1992:86, 197-201) gebruik Paulus die woord nomo ook soms in ' $n$ baie breë sin, deurdat dit dikwels die totale Joodse lewenswyse, en alle Joodse tradisies as referent het.

ii Die tweede antitese wat hy vermeld is dat die nuwe verbond geregtigheid bewerkstellig, terwyl die ou verbond lei tot veroordeling. Barnett (1997:182) stel dit soos volg: 'Thus, spiritually speaking, it "kill[ed]" the people, and rendered the old covenant a "ministry of death".

iii Derdens, is die nuwe verbond, volgens Paulus, onverganklik, terwyl die oue verganklik is (katargoumenhn: "abolished"; "obsolete"; "cease"; "invalidate"; "put an end to"; "be freed" Louw \& Nida [1989:135]; Klauck [1988:37]). 'n Belangrike implikasie, voortspruitend uit Paulus se apologia hierbo, is die feit dat die ou verbond skynbaar nie langer enige relevansie het vir die Christelike kerk nie. Lambrecht (1999:47) stel dit soos volg: "The highly astonishing but inevitable consequence is that what Moses brought is no longer relevant... The denigrading way in which Paul refers tot the old covenant and its law in 3:3 and 6 cannot but surprise the reader".

Gager (2000:14) verwerp die sogenaamde tradisionele "rejectionreplacement view" waarvan die aanhaling uit Lambrecht hierbo "n goeie voorbeeld is. Hiervolgens het Paulus se evangelie die Judaïsme en die Torah vervang as legitieme weg tot God vir Jode sowel as heidene. Volgens Gager (2000:66-75) was Paulus egter tot met sy dood steeds ' $\mathrm{n}$ suiwer Judaïs en Fariseër (sy "bekering" was slegs 'n roeping tot, en nie " $n$ bekering wég van die Judaïsme nie), en kan alle anti-Joodse opmerkings deur Paulus in byvoorbeeld Galasiërs sowel as Romeine (Ibid 76152), verklaar word aan die hand van ' $n$ eenvoudige hermeneutiese sleutel, naamlik dat sy gemeentes uitsluitlik uit heidene bestaan het wat nie die Joodse wet nodig gehad het om gered te word nie. Volgens Gager bly die Torah egter steeds normatief vir alle Jode - al word hulle Christene. By nadere ondersoek blyk Gager se hermeneutiese sleutel egter nie so aanvaarbaar nie, en die teendeel blyk duidelik uit 'n noukeurige eksegese van 1 en 2 Korintiërs $^{8}$. Den Heyer (2000:281-282) is van mening

8 In Handelinge 18:1-11 word vertel hoedat Paulus sy arbeid in Korinte in die sinagoge begin, en later vanweë teenstand met sy bekeerlinge skuif na die huis van 
dat, alhoewel Paulus trots was op sy Joodse agtergrond, hy homself tog ook duidelik daarvan gedistansiëer het ${ }^{9}$. In Filippense 3 beskryf Paulus immers sy eertydse ywer as Fariseër, sy besnydenis en sy onderhouding van die wet as zhmi a ("n verlies of "loss" - Louw \& Nida [1989:113]) en skubala (drek of "rubbish" - Louw \& Nida [1989:224]). Martin (1995:85) ondersteun hierdie perspektief op die volgende wyse:

"Expressions such as the old and the new, the flesh and the spirit, the ministry of death and the ministry of the spirit (2 Cor 3:7-8), the end of the law (Rom 10:4) versus the law of the Spirit (Rom $8: 2$ ), etc., do not allow any doubt that for Paul the new age, and consequently the new Israel, were not to be the fruit of a patient evolution, but rather a sudden leap, a significant mutation".

C ' $n$ Derde motief wat in hierdie gedeelte figureer, is dié van heerlikheid.

Vanaf vers 7 tot 18 vergelyk Paulus die heerlikheid van die twee verbonde met mekaar. Die waarheid wat Paulus wil beklemtoon, is die veel groter heerlikheid van die nuwe verbond ( $p$ ollw w mallon perisseuei hJ diakonia th' dikaiosunh doxhy). Volgens Klauck (1988:37), Barnett (1997:179) en Lambrecht (1999:61) is die sentrale onderliggende tema van dié perikoop, dié van heerlikheid (doxa). Volgens Paulus is dit noodwendig so dat die bediening van die Gees veel meer heerlikheid ( $\mathrm{p}$ ol I w/ma I I on per is s euei) behoort te manifesteer as die verbond van die dood (Fung 1982:133, 134). Die heerlikheid van die nuwe verbond manifesteer wanneer mense geestelik lewend gemaak word, geregverdig word (v9), vry gemaak word van die vereistes van die ou verbond (v11), meer vrymoedigheid en bekwaamheid ervaar (v12), openbaringskennis ontvang (vv14-16), groter geestelike vryheid geniet (v17) en laastens, deur die Gees getransformeer word van heerlikheid tot heerlikheid (v18). Die nuwe verbond is dus 'n manifestasie van die krag van die Gees wat die dood in al sy fasette neutraliseer. Tesame met die vereiste dat die bediening van die nuwe verbond die Gees van God (vv3,6), sowel as Christus (v4) as basis het, funksioneer die vermelde dimensies van vryheid waarskynlik tegelyk as die vrug van die Pauliniese bediening, sowel as die kriteria vir ware Pauliniese bediening.

Titius Justus. Selfs Krispus, of ajcis unagwgor, en sy hele huisgesin het tot bekering gekom en by die huiskerk aangesluit - 'n feit wat Gager se argument van 'n suiwer heidense kerk in Korinte neutraliseer (Den Heyer 2000:134).

9 Engberg-Pedersen (2000:33-80) beskryf duidelike paradigmatiese ooreenkomste betreffende bekering in Paulus se briewe, en bekering soos verstaan deur die Stoïsyne. By beide word ' $n$ totale wegdraai van jouself (ou identiteit) na die groep (nuwe identiteit) vereis. Alles word nuut - die oue is verby; die nuwe het gekom. 
Hierdie oorwinning van die lewe oor die dood, blyk ook uit tekste soos Romeine 7:7, 8; 1 Korintiërs 15:45, 56 (Kremer 1990:38).

\subsection{Die Pauliniese kerkleier as shaman-tipe middelaar}

Volgens 2 Korintiërs 3:6 hierbo, beskou Paulus homself skynbaar nie alleen as ' $n$ verkondiger van die woord nie, maar ook as ' $n$ bemiddelaar, bedienaar en fasiliteerder van die manifestasie of werking van die Heilige Gees wat uitmond in nuwe lewe vir dié wat bedien word. Funksioneel kan die Pauliniese kerkleier dus vergelyk word met die sogenaamde shaman. Ashton (2000:32) fokus op die sosiale tipe van die sogenaamde shaman, wat transkultureel en universeel funksioneer in godsdienste, in sy poging om Paulus in " $n$ godsdiens-historiese raamwerk te plaas. Wilson (1980:84) verkies die term "intermediary" (tussenganger of bemiddelaar), in plaas van shaman, omdat dit volgens sy oordeel waarskynlik meer neutraal is. Wilson werk ook met dieselfde godsdiens-historiese perspektief ten opsigte van profetisme. Die term shaman, het volgens Ashton (2000:32, 33) sy oorsprong in die Tungu-stam van Siberië. 'n Shaman word soos volg gedefiniëer:

"the term shaman refers to persons of both sexes who have mastered the spirits, who at their will can introduce these spirits into themselves and use their power over the spirits in their own interests, particularly helping people who suffer from the spirits; in such a capacity they may possess a complex of special methods for dealing with the spirits".

Die lewe van die shaman kan verdeel word in die volgende fases (Ashton 2000:33; Craffert 1999:326-327):

i hulle vroeë lewe;

ii hulle roeping wat gewoonlik " $n$ trans of ander bonatuurlike gebeurtenis insluit;

iii hulle bediening wat gekenmerk word deur hulle bonatuurlike vermoëns (soos reise in die geesteswêreld, die doen van wonders, ekstatiese ervarings, genesings, eksorsisme), hulle krag oor die geeste en die geesteswêreld, en hulle prominensie in die samelewing (Craffert 1999:326).

iv Die uitstaande kenmerk van alle shamans is hulle vermoë om as " $n$ "telefoonverbinding" (medium) tussen individue en die godheid te funksioneer (Craffert 1999:327).

Witherington (1998:154) bevestig hierdie perspektief ten opsigte van Paulus soos volg: 
"The combination of prophecy and the work of the Spirit made Paul a powerful figure to reckon with. He could deliver more than just spiritual words: he was a conduit for spiritual works as well. $\mathrm{He}$ was in some respects like the charismatic performance prophets of old, such as Elijah and Daniel. The reaction to Paul as the true Hermes, the true messenger of God, depicted in Acts 14:818 was certainly not atypical... Charismatic leaders always rattle the cage of institutional leaders, especially when they claim to answer solely or almost solely to God".

Die afleiding wat mens waarskynlik kan maak uit bogenoemde, is dat die meeste aspekte rakende die bediening van die nuwe verbond, volgens Paulus, pneumatologies gefundeer is. God alleen stel jou in staat om as bedienaar van die nuwe verbond die krag van die Gees te bedien of te bemiddel, wat lei tot nuwe lewe vir die wat bedien word. Klauck (1988: 47) bevestig hierdie afleiding soos volg: "Der Neue Bund ist ein geistgewirktes endzeitliches Phänomen, das die prophetischen Verheibungen einlöst”.

Paulus maak daarop aanspraak dat sy bediening met tekens en wonders in die krag van die Heilige Gees plaasgevind het (Rom 15:18, 19). Hy herinner die Korintiërs daaraan dat hulle sal onthou dat toe hy vir hulle gepreek het, dit nie net met wyse en oorredende woorde was nie, maar met 'n sigbare demonstrasie van Gees en krag sodat hulle geloof nie alleen sou berus op sy woorde nie, maar in die sigbare krag van God self (Lambrecht 1999:47; 1 Kor 2:4,5). Verder verklaar Paulus dat hy, wanneer hy Korinte besoek, nie beïndruk sal word deur die welsprekendheid van die sogenaamde "superapostels" wat die gemeente verwar het en hom aangeval het nie, maar eerder sal kyk wat hulle kan doen. Die koninkryk van God is volgens hom immers "nie "n saak van praatjies nie, maar van krag" (1 Kor 4:20).

\section{ELLIS SE KLASSIFIKASIE VAN DIE EIENSKAPPE VAN DIE PAULINIESE BEDIENING}

Ellis (1988:47-50) sluit by Paulus se argument in 2 Korintiërs 3 aan, deur te wys op drie eienskappe van die bediening wat hy by Paulus vind $^{10}$ :

\section{Die eskatologiese karakter van bediening}

Oral waar ware Nuwe-Testamentiese (in dié geval Pauliniese) bediening plaasvind, kom die koninkryk van God waarskynlik op 'n sigbare of

10 Bartlett (1993:54) bevestig Ellis se perspektief deur te wys op die charismatiese aard van die Pauliniese bedieninge, die interpersoonlikheid daarvan en ook die dienskarakter daarvan. 
onsigbare wyse. Die pauliniese bediening staan in die teken van die koms van die Seun van God. Hy is die groot middelaar/bedienaar. Mense word as gevolg van die kruis van Golgota uit die ruimte van die eerste Adam verplaas na die ruimte van die laaste Adam wat "n "lewendmakende Gees" geword het. Mense is in die antieke tyd as deel van korporatiewe realiteite beskou. Jy was deel van Adam (sonde) of deel van Christus (verlossing). Volgens Paulus moes die bediening die oorgang van die een na die ander bemiddel (Ellis 1988:5,10-17).

\section{Die charismatiese aard van bediening}

Die gawe-aspek van die Pauliniese bediening impliseer dat ware bediening gewoonlik nie plaasgevind het suiwer vanweë natuurlike vermoëns, akademiese kwalifikasies of institusionele formules nie. Paulus en al die ander bedienaars het bedien omdat hulle deur Christus geroep (volgens Efesiërs 4:7-16), en deur die Gees begaaf is. Die Pauliniese bediening het dus waarskynlik ' $n$ christologies-pneumatologiese basis. Küng (in Fung 1984:10) sluit soos volg by Ellis se standpunt aan:

"Charism and diakonia are correlative concepts. Diakonia is rooted in charisma, since every diakonia in the church presupposes the call of God. Charisma leads to diakonia, since every charisma in the church only finds fulfilment in service. Where there is real charisma, there will be responsible service for the edification and benefit of the community".

Hierdie waarheid het belangrike implikasies vir die hedendaagse kerk. Kahmann $(1978: 43,44)$ formuleer hierdie verantwoordelikheid soos volg:

"In een tijd echter als de onze, waarin de betekenis van de charismata voor het leven van de kerk opnieuw is ontdekt en erkend, krijgt het oorspronkelijk Paulinisch model een nieuwe actualiteit. Waar de kerk steeds in ontwikkeling is, lijkt het ogenblik gekomen om aan dit model binnen de hiërargische struktuur nieuw reliëf te geven. Dit zou beteken dat de hiërargische het als een van haar voornaamste taken gaat beschouwen, de ontplooiing van de charismata binnen de kerk, in al hun verscheidenheid, positief te bevorderen en de werking ervan te bundelen tot steeds grotere vitaliteit van de kerk naar binnen en naar buiten. De hiërargische leiders zijn tenslotte zelf op de eerste plaats geroepen om charismatisch te functioneren".

Bartlett (1993:56) formuleer sy eie versugting in die dié verband soos volg: 
"Contemporary structures need to be found that will combine charisma with order, Spirit with structure. For our day as for Paul's, it is the Spirit we most need to affirm and pray".

McIntyre (1997:284) deel ook hierdie sentment:

"Yet in order that we may as a church reap the full benefits of such commitment, we have to begin by recognizing wholeheartedly the obligation to affirm the doctrine of the Holy Spirit and to acknowledge the need for his presence in our midst, with the seriousness with which we have in centuries past honoured Jesus Christ, both in his person and in his redemptive works".

Hierdie manifestasie van die Gees het ten doel die s umf er on van almal. Hierdie woord beteken "om beter daaraan toe te wees as voorheen" (Louw \& Nida 1989:65:44). Behalwe vir die maatstaf van voordeel (nuttigheid) waaraan alle charismata gemeet moet word, is daar ook die trinitariese kriterium; die belydeniskriterium (12:1-3); die dienskriterium (vv12-30); die liefdeskriterium (13:1-13), en die opboukriterium (12:140; 2 Kor 10:8). Volgens Paulus behoort alle Heilige Gees geïnspireerde bediening altyd so ver moontlik aan hierdie vyf kriteria te voldoen (Bezuidenhout 1980:339-349; Louw 1997:216-217).

\section{Die diverse aard van bediening}

Volgens Ellis is die meeste gawes gerig op die opbou van die gemeente (profesie, uitleg van tale, ens). Sommige is egter gerig op buitestaanders (evangelisasie, apostelskap, ens), en ander is weer hoofsaaklik gerig op God (tale). Die Pauliniese bediening het ook nie slegs ongestruktureerd plaasgevind nie, maar Paulus gee juis aan die Korintiërs voorskrifte vir die ordelike hantering van die gawes tydens eredienste.

\subsection{Tweede gevolgtrekking}

Op grond van die eksegese van 2 Korintiërs 3 hierbo, is dit moontlik om te konkludeer dat Paulus sy konsep van die Nuwe-Testamentiese bediening sterk pneumatologies gefundeer het. Kerkleiers het die krag en dinamiek van die Heilige Gees aan ander gelowiges bemiddel, en in die proses as middelaars tussen God en mens opgetree.

\section{DIE “SKAT IN ERDEKRUIKE”}

Een van die manifestasies van die reeds vermelde groter heerlikheid van die bediening van die nuwe verbond, is die teenwoordigheid van groter nederigheid. Hierdie bediening van die Gees wat in heerlikheid plaasvind (2 Korintiërs 3:8) gee bedienaars soos Paulus nie die reg om hulleself te verhef bo ander gelowiges nie. Inteendeel, Paulus verklaar net ' $n$ paar verse later in 2 Korintiërs 4:7, dat God die heerlikheid (doxa) van 
hierdie skat (qhsauron), juis in nederige, aardse erdekruike (ojtrakinoi skeuesin) plaas, sodat (iha) die voortreflikheid (uperbol h;) van hierdie krag (t $h \sim$ dunamew ) God vereer, en nie vir Paulus en sy medewerkers nie. Hierdie analogie wat Paulus aanwend om die bedienaars van die nuwe verbond te beskryf, beklemtoon die feit dat God alleen die bron is van die heerlikheid wat manifesteer in die bediening van die nuwe verbond. Verder manifesteer hierdie heerlikheid, volgens Paulus, heel dikwels in tye van uiterste swaarkry aan die kant van die apostels (vv8-12). Terwyl die dood in hulle werk, manifesteer die lewe in die gemeente! Hierdie aspek van die bediening raak aan dimensies van die woorde, diakonia, uphreth , l eitourgia en doul $0 \sim$ waarop vroeër gewys is (5). Selfs bedienaars van die heerlikheid van die nuwe verbond bly steeds maar diensknegte van God en die kerk. Enige self-verheerlikende gesindheid lei, volgens Paulus, tot sekere selfdiskwalifikasie uit die bediening van die nuwe verbond.

\section{SAMEVATTENDE OPMERKINGS}

Daar is ' $\mathrm{n}$ skynbare tweeledigheid in Paulus se beskrywing van die wesensaard en die funksies van ' $n$ kerkleier. Die eerste dui op die dimensie van diens (dien), terwyl die tweede dui op die pneumatologiese dimensie (bédien die realiteit van die Heilige Gees). Die onderskeid wat dikwels in kerke tussen die diakonia (die sogenaamde amptelike of formele bediening wat deur Kahmann hierbo as die "hiërargische" dimensie beskryf word) en die charismata getref word is skynbaar vreemd aan die Pauliniese bediening wat beide insluit. Ridderbos (1975:444-445) is ook van mening dat diakonia glad nie charismata uitsluit nie, maar dat charisma juis moet oorgaan in diakonia, en dat diakonia juis deur die charismata verryk behoort te word. Beide hierdie dimensies word omsluit deur die motief van nederigheid. Die Pauliniese bediening word dus nie noodwendig alleen gekenmerk deur die dramatiese, die sensasionele en die ekstatiese nie, maar ook deur die diensgestalte daarvan (Louw 1997:216; Ridderbos 1975:444-445). Die titel van hierdie artikel: "Leiers wat dien en bédien", is dus waarskynlik gepas, omdat dit beide hierdie dimensies van die Pauliniese diakonia verreken. ' $n$ Voorlopige definisie van Pauliniese kerkleiers kan waarskynlik soos volg geformuleer word:

' $n$ Pauliniese kerkleier is iemand wat die leiding neem ten opsigte van dienslewering in die kerk, en wat ook deur God se Gees begaaf is om as ' $n$ geestelike middelaar van die nuwe verbond op te tree tussen God en mense, in 'n gesindheid van nederigheid en afhanklikheid van God. 


\section{Literatuurverwysings}

Ashton, J 2000. The religion of Paul the apostle. London: Yale University Press.

Barnett, P 1997. The second epistle to the Corinthians. Grand Rapids: W B Eerdmans Publishing Company.

Bartlett, D L 1993. Ministry in the New Testament. Minneapolis: Fortress Press.

Bass, B M 1990. Bass \& Stogdill's handbook of leadership. Theory, research and managerial applications, $3^{\text {rd }}$ ed. New York: The Free Press; London: Collier Macmillan Publishers.

Bennis, W G \& Nanus, B 1985. Leaders: The strategies of taking charge. San Fransisco: HarperCollins.

Beyer, H W 1985. s v Diakonos, in: Kittel \& Friedrich (eds), Theological Dictionary of the New Testament. Grand Rapids, Michigan: William B Eerdmans Publishing Company (one volume edition by G Bromiley).

Bezuidenhout, M E J 1980. Pauliniese kriteria ten opsigte van die beoefening van die charismata - 'n eksegetiese studie van 1 Kor 12-14. Ongepubliseerde DD-proefskrif. Universiteit van Pretoria.

Brister, C W 1983. The ministry in 1 Corinthians. Southwestern Journal of Theology 26, 19-32.

Collins, J N 1990. Diakonia: Re-interpreting the ancient sources. Oxford: Oxford University Press.

Craffert, P F 1999. Jesus and the shamanic complex: first steps in utilising a social type model. Neotestamentica, 33(2), $321-42$.

Den Heyer, C J 2000. Paul: A man of two worlds. Harrisburg: Trinity Press International.

Donfried, K P 1992. Ministry - reality or myth? Rethinking the term Diakonia. Dialog 31, 121-128.

Du Rand, J A 1988. Charisma en amp - ' $n$ Pauliniese eksegetiese verkenning, in: Rossouw, P J (red) Gereformeerde Ampsbediening, 75-94. Pretoria: N G Kerkboekhandel.

Ellis, E E 1988. Pauline theology. Ministry and society. Grand Rapids: Paternoster Press.

Engberg-Pedersen, T 2000. Paul and the Stoics. Edinburgh: T \& T Clark.

Fung, R Y K 1982. The nature of the ministry according to Paul. The Evangelical Quarterly 54, 129-146 JLS.

-, 1984. Ministry, community and spiritual gifts. The Evangelical Quarterly 56, 3-20.

Gager, J G 2000. Reinventing Paul. Oxford: Oxford University Press.

Green, H 1996. 'n Prakties-teologiese ondersoek na die rol van die leraar as leier in die gemeente. Ongepubliseerde DD-proefskrif. Universiteit van Pretoria.

Kahmann, J J A 1978. Ambt en dienst in de kerk van het Nieuwe Testament, in: Blijlevens, A J M (red). Ambt en bediening in meervoud. Hilversum: Gooi en Sticht. 
Klauck, H J 1988 2. Korintherbrief. Würzburg: Echter Verlag (Die neue Echter Bibel).

Kremer, J 1990. 2 Korintherbrief. Stuttgart: Katholisches Bibelwerk (Stuttgarter Kleiner Kommentar - Neues Testament 8).

Lambrecht, J 1999. Second Corinthians. Collegeville, Minnesota: The Liturgical Press (Sacra Pagina Series, Vol. 8).

Louw, D J 1997. Pastoraat as vertolking en ontmoeting. Teologiese ontwerp vir ' $n$ basisteorie, antropologie, metode en terapie. Kaapstad: Lux Verbi.

Louw, J P \& Nida, E A (eds) 1989. Greek-English Lexicon of the New Testament based on semantic domains 2 vols. Cape Town: Bible Society of South Africa.

Lidddell \& Scott 1989. An intermediate Greek-English Lexicon. Founded upon the seventh edition of Liddell and Scott's Greek English Lexicon. Oxford: Clarendon Press.

Marshall, T 1991. Understanding leadership. Fresh perspectives on the essentials of New Testament leadership. Chichester: Sovereign World.

Martin, V 1995. A house divided. The parting of the ways between Synagogue and Church. New York: Paulist Press.

Maxwell, J C 1991. The 21 irrefutable laws of leadership. Follow them and people will follow you. Nashville: Thomas Nelson Publishers.

McIntyre, J 1997. The shape of pneumatology. Edinburgh: T \& T Clark.

Messer, D E 1989. Contemporary images of Christian ministry. Nashville: Abingdon Press.

Ridderbos, H 1975. Paul: An outline of his theology. Grand Rapids Michigan: Wm. B. Eerdmans Publishing Company.

Schweizer, R E 1992. s v Ministry in the early church, in: Freedman, D N (ed), The Anchor Bible Dictionary vol 5, 835-842. New York: Doubleday.

Stogdill, R M 1981. Handbook of leadership: A survey of the literature. Revised and expanded edition by Bernard M Bass. New York: Free Press.

Wehrli, E S 1992. Gifted by their Spirit. Leadership roles in the New Testament. Cleveland, Ohio: The Pilgrim Press.

Wilson, R R 1980. Prophecy and society in ancient Israel. Philadelphia: Fortress Press.

Winger, M 1992. By what law? The meaning of Nomo; in the letters of Paul. Atlanta: Scholars Press (SBL Dissertation Series).

Witherington, B 1998. The Paul Quest: The renewed search for the Jew of Tarsus. England: Inter-Varsity Press. 